\title{
Single Parenting: Understanding Reasons and Consequences
}

\author{
Shumaila Khadim Ali and Sarmad Muhammad Soomar* \\ Aga Khan University School of Nursing and Midwifery, Pakistan
}

Submission: January 04, 2019; Published: January 22, 2019

*Corresponding author: Sarmad Muhammad Soomar, Aga Khan University School of Nursing and Midwifery, Pakistan

\begin{abstract}
Family is a great institution and parenting is its pillar. However, with time there have huge observations that single parenting is mostly practiced and one individual parent is accountable of nurturing of children. Due to multiple reasons both spouses are unable to practice the same responsibilities together. It seems very strong but has ultimate consequences on children. Connecting with some theories that relate parenting, this paper aims to highlight common contextual reasons and consequences of single parenting.
\end{abstract}

Keywords: Parenting; Reasons; Consequences; Children; Single parenting

\section{Introduction}

One of the vital aspects of society is family. It's a primary source whom young born interacts and mingled with. The family's most significant and extraordinary duty is to arrange and lift the youngsters within the standards and estimations of the society. Parents facilitate their children in each step of their life and love them unconditionally. However, as a result of single parenting this love and warm heartedness is seemed to decrease that directly have an effect on child's overall health status and upbringing $[1,2]$.

The family is a huge institution and parenting is supporting and establishing pillars. Parents are responsible to teach children about the norms and values of society and accountable for developing psychological and emotional well-being. In our society single parenting is not much acceptable. Societies stigmatize single parents and their offspring's [1]. In Pakistan Particularly, single mothers are more stigmatized because of patriarchy [2]. Culturally it's not acceptable to live with opposite gendered parent. A parent conjointly leaves remarkable impacts on children's behaviors, personality and health. In our context, a girl cannot share every little matter with her father as she can do easily with her mother and vice versa [2].

These all social and cultural factors influence our work to explore the underpinnings of this very common phenomenon. Single parenting is defined as a parent either father or mother alone practicing and taking responsibility of nurturing children in the absence of another parent [1,2]. Around 40,410 cases of parent's separation have been reported in the family court of Pakistan, which eventually led to single parenting [2]. On the hand, 320 million children globally, or particularly one in every seven children is living with single parent predominantly with mother [3].

\section{Reasons of single parenting}

There are many reasons of parent's separation that can leave all the responsibilities in the hand of single parent. One major reason of being separated in Pakistan is divorce. Estimated more than 100 cases of divorce are registered in family courts of Pakistan on everyday basis [2]. Other major cause that lead to single parenting is teenage or unintended pregnancy. Every year 7.3 million young girls get pregnant which eventually lead to forceful marriages, and these marriages usually don't stay for long term thus lead to separations which consequently result in single parenting. Death of spouse due to any illness or other cause and maternal morbidities and mortality also lead to single parenting [3].

\section{Related Theories}

\section{Albert Bandura-social learning theory}

The main focus of social learning theory is to observe and imitate the behaviors, emotions and attitude of others. Hence, it focuses on learning by means of observing and modeling. Children do their initial interaction with their families, observe and learn the actions of care givers [4]. In single parenting the child has only one parent to look at and copy its actions. It is very important and vital to have both parents so that children may not fall in Oedipus complex. 
According to Bandura, children learn behaviors from their families. If parents are irresponsible in some manner the child will learn same. If parent haven't built trustworthy relationship with their children, there are higher probabilities that children will face difficulties in forming good relationship with their surroundings. Thus, a positive result can be accomplished only if parents demonstrate the kind of behavior which they want their children to learn [4].

\section{Operant conditioning theory by B.F Skinner}

Operant conditioning which means changing of behavior by providing reinforcement after desirable behavior was presented by Skinner [5]. Reinforcement and punishments are most important aspects of learning. Parents use these methods to strengthen the desired behavior and weaken the undesired one. For example, if a child is being provided with his favorite toy by his or her mother for doing assignment on time, then there is highest probability that he will repeat this behavior because of reinforcement $[4,5]$.

On the other hand, if the child was scolded by her mother for not doing assignment on time then he will learn that such behavior only earns condemnation and therefore he modifies his behavior accordingly. In general, single parent focuses on earning and providing basic necessities of life to their children and tends to ignore child's unwanted behavior that can create problem for children in future. So, it is very important for parents to reward desirable behavior and punish them for undesired behavior so that they can learn which behavior is good and which is not good [5].

\section{Erik Erikson psychosocial theory}

Psychosocial theory was given by famous psychologist Erik Erikson. This theory consists of eight stages that cover up all the stages of individual's life, i.e. from infancy to late adulthood. These stages are trust versus mistrust, autonomy versus shame / doubt, initiative versus guilt, industry versus inferiority, identity versus identity confusion, intimacy versus isolation, generativity versus stagnation and integrity versus despair [6]. All these stages contain conflict that leaves positive and negative impacts on individual's personality. Erikson called these conflicts as crisis that need to be resolved before moving to next stage. There is a chance that the child of single parent experience crisis on all stages. For instance, in the initial stage of infancy, the child wants their caregiver to be approachable to feed them, relieve their anxiety and make them laugh. However, single parent cannot fulfill their needs and expose them to crisis $[5,6]$. All these dissatisfactions may lead to hopelessness and other psychological problems like depression.

\section{John Bowlby attachment theory}

Attachment is a basic human need for secure relationship between children and care giver. A child psychiatric John Bowlby gave theory of attachment which clearly explains that how children and parent relationship emerges and how it influences the emotional and social development of child. Four stages of attachment were designed by Bowlby. These stages begin from infancy. Theses stages are pre-attachment, attachment in making, clear cut attachment, and formation of reciprocal relationship. All these stages build a bond and this bond binds parents and children emotionally [7].

Another three stages were described by the colleague of John Bowlby that are experienced when children are being separated from their care givers. These stages are detachment, protest, and despair (8). In case of single parenting, parent is not able to build stronger relationship then there are higher chances that children will face some problems, they may suffer from psychological disorders, social difficulties and irretrievable developmental consequences, such as decrease intelligence, increase anger and violent behavior $[7,8]$.

\section{Consequences}

Children of single parent may spend quite stressful life as compared to those children that live with two parents that is both mother and father. Many researches have been conducted that reveals that single parenting has many effects on child's academic performance, economic hardship, social interaction and it negatively influenced child's health. Financial instability or financial crisis is the main, consistent issue that is faced by most of the single parents [8].

Children who are nurtured by single parents are usually inattentive or pay less concentration in schools and may often quit or leave schools before certain qualification and if they complete their education then they did not show interest in works or jobs as a result they left unemployed. That again effects their emotional and behavioral development [9]. Quality of time is usually not provided by single parents to their children. Such as listening child's concerns, understanding their emotional and psychological needs and help them in their assignments, asking them about their studies.

Single parents are unable to perform all these tasks because of their busy schedules of managing different parenting roles and due to financial or economic causes or crisis. [7]. Together with monetary and social issues child with single parent also face issues related to health. Because of no health insurance, poor standard of living and almost negligible or reduced quality of care by single working parent which increase stress in child's life. All these issues and explosive factors of single parenting also impacts child's psychological well-being and leads to feeling of violence, anxiety, depression, anger, isolation, lack of social interaction, negative perception for self and sometimes leads to suicidal ideation. Therefore, as a result child may engage in unconstructive or unacceptable behaviors such as alcohol use, smoking, substance abuse, violation, harming others and suicidal attempts to release tension or for feeling of relief from their emotional pain $[8,9]$.

\section{Recommendations and Conclusion}

Despite of only stigmatizing the single parents and their children we all as a community should help them in fulfilling their 
requirements or needs to make their life valuable and provide them a platform for worth living. Firstly, before getting separated, parents should try to maintain stability in their relationship for better future of their children. If they fail to maintain stability, then both parents should contribute or share equal responsibilities for better upbringing and to enhance intellectual and emotional development of their children. Secondly, all the higher authorities such as Non-governmental organizations, counselors, psychologist.

Parent teacher associations and social workers should plan sessions to train and educate single parents about how to deal with multiple challenges that come across their way. Workshops, media and seminars can be helpful to create insight in parents regarding their responsibilities. Lastly, it is suggested that government and non-governmental organizations should support financially, and in all aspects, to secure the future of children. Moreover, government should midline the policies that parenting is relatable to both spouses, if they even decided to get at one side but their roles should be considered accountable for children, even they separate. In the end, quality of time or care and proper attention to children is the most important task of parents. However, single parenting seems to be very predominant and common social issue now days around the globe.

Children nurtured by single parent due to multiple reasons most commonly because of divorce, death of the spouse, unintended pregnancies, adoption that consequently leads to many problems such as psychological trauma, mental health and behavioral issue, financial hardship, low performance at school or colleges, low self-esteem, decreased social interaction and poor life style. Most important thing is to understand and respect the significance of parenting either it is single of individual.

\section{References}

1. N Mabuza, SK Thwala, CIO Okeke (2014) Single Parenting and Its Effects on the Psychosocial Development of Children in Swaziland. Mediterranean Journal of Social Sciences 5(23).

2. Falana B, Bada F, Ayodele C (2012) Single-parent Family Structure, Psychological, Social and Cognitive Development of Children in Ekiti State. Journal of Educational and Developmental Psychology 2(2).

3. Frankel L, Hughes S, O'Connor T, Power T, Fisher J, et al. (2012) Parental Influences on Children's Self-Regulation of Energy Intake: Insights from Developmental Literature on Emotion Regulation. Journal of Obesity, p. 12.

4. Mooney A, Oliver C, Smith M (2009) Impact of Family Breakdown on Children's Well-Being: evidence review $\left(1^{\text {st }}\right.$ edn). Dept. for Children, Schools and Families 2009, Institute of Education, University of London, UK.

5. Hong E, Park S (2012) Impact of attachment, temperament and parenting on human development. Korean J Pediatr 55(12): 449-454.

6. Abrhiem H (2014) The Role of Parenting Styles in Psychosocial Development of Adolescents. Business and Management Review $3(11): 47-52$

7. Connor T, Scott S (2007) Parenting and outcomes for children. Joseph Rowntree Foundation North Yorkshire.

8. Chapman P, Whitfield L, Felitti J, Dube R, Edwards J, et al. (2004) Adverse childhood experiences and the risk of depressive disorders in adulthood. J Affect Disord 82(2): 217-225.

9. Bornstein H, Bradley H (2014) Socioeconomic status, parenting, and child development. Journal of Early Adolescences.

\section{Your next submission with Juniper Publishers} will reach you the below assets

- Quality Editorial service

- Swift Peer Review

- Reprints availability

- E-prints Service

- Manuscript Podcast for convenient understanding

- Global attainment for your research

- Manuscript accessibility in different formats

( Pdf, E-pub, Full Text, Audio)

- Unceasing customer service

Track the below URL for one-step submission https://juniperpublishers.com/online-submission.php 